\title{
ЭКОНОМИЧЕСКАЯ ЭФФЕКТИВНОСТЬ АНТИМОНОПОЛЬНОГО КОМПЛАЕНСА ДЛЯ ПРЕДПРИНИМАТЕЛЬСКИХ СТРУКТУР
}

\author{
(c) 2018 Плетешков Александр Николаевич \\ аспирант \\ Санкт-Петербургский университет технологий управления и экономики \\ 190103, Санкт-Петербург, Лермонтовский проспект, 44 \\ E-mail: axenus@bk.ru
}

В статье рассматриваются проблемы внедрения и оценки эффективности такого сравнительно нового для России института как антимонопольный комплаенс. Рассматриваются цели и задачи внедрения антимонопольного комплаенса на уровне предпринимательских структур. Анализируются имеющиеся подходы к оценке эффективности внедрения антимонопольного комплаенса.

Ключевые слова: антимонопольный комплаенс, экономическая эффективность, антимонопольное законодательство, конкуренция.

Проблема повышения эффективности деятельности российских предприятий неразрывно связана с действием такого, сравнительного нового для России института как антимонопольный комплаенс, представляющий, если говорить в общем, систему инструментов и механизмов снижения вероятности нарушения антимонопольного законодательства на уровне предприятий (хозяйствующих субъектов). Целью функционирования подобной системы представляется предупреждение возникновения и минимизация антимонопольных рисков, что, в свою очередь, ведет к снижению связанных с этим соответствующих антимонопольных санкций [6].

В докладе аналитического Центра при Правительстве Российской федерации антимонопольный комплаенс трактуется как система внутрикорпоративного предупреждения нарушений антимонопольного законодательства [2]. Наконец, законодательно, антимонопольный комплаенс определяется как «Система внутреннего обеспечения соответствия требованиям антимонопольного законодательства (антимонопольный комплаенс) - совокупность правовых и организационных мер, предусмотренных внутренним актом (актами) хозяйствующего субъекта либо другого лица из числа лиц, входящих в одну группу лиц с таким хозяйствующим субъектом, если такие внутренние акты распространяются на такого хозяйствующего субъекта, и направленных на соблюдение им требований антимонопольного законодательства и предупреждение его нарушения» [10].

Дальнейшее развитие понятие антимоно- польного комплаенса получает уже в нормативных документах, регламентирующих его функционирование (как системы) непосредственно в компаниях. Так, он понимается, например, как совокупность правовых и организационных мер, направленных на обеспечение соответствия деятельности Компании и ОКС НН (Норильский Никель) требованиям антимонопольного законодательства, профилактику, предупреждение, выявление и пресечение его нарушения [7]. То же самое касается и такого предприятия как ОАО «Ятек» и др.

Возникновение самого антимонопольного комплаенса (во всяком случае для предприятий), как следует из нормативных документов и научной литературы. непосредственно связано с теми потерями, которое предприятие несет (или может понести) вследствие нарушения антимонопольного законодательства. На наш взгляд, это только одна сторона вопроса, необходимо рассмотреть экономические аспекты внедрения антимонопольного комплаенса, т.е. соотнести затраты и результаты.

Нужно отметить, что на вербальном уровне подобные попытки уже делались. Так, в качестве примера можно привести ряд мнений о преимуществах и негативных сторонах комплаенс-функции. В качестве позитивных последствий признаются предотвращение и минимизация финансовых потерь, банкротства и санкций применительно к компаниям со стороны российских и зарубежных регуляторов, отлаженная система обнаружения и предотвращения явлений мошенничества, коррупции и другого 
рода угроз бизнесу, сохранение и развитие деловой репутации компаний и, наконец, повышение эффективности деятельности, увеличение конкурентоспособности, инвестиционной привлекательности и стоимости корпорации [1]. Позитивным для предпринимательских структур, внедривших системы антимонопольного комплаенса признано снижение штрафа или освобождение от проверок [5].

Сравнительно мало работ по соотношению позитивных и негативных последствий внедрения системы антимонопольного комплаенса, т.е. ее эффективности, в основном на вербальном уровне [3]. При этом, практически ничего не говорится об экономической эффективности для всех участников этого процесса, в первую очередь, для предприятий. Тем не менее, ряд авторов рассматривает вопросы экономической эффективности, однако не всегда учитывает затраты и результаты. Так, Тимошкин А.В. [8], рассматривая эффективность комплаенс-контроля на примере банковских структур, приводит данные, что «прямые затраты Дойче Банка в 2005 г. составили 100 млн. евро, именно столько банк инвестировал в информационные системы и человеческий капитал своей комплаенс-функции» [8]. Естественно, что предприятия создавая систему антимонопольного комплаенса должны рассматривать не только возможные позитивные последствия внедрения подобной системы, но и оценивать потенциальные затраты с целью их минимизации и, соответственно, оптимизации получаемого результата. В то же время к основным издержкам деятельности комплаенс-контроля в банковской сфере автор относит «упущенную выгоду финансовых организаций из-за отказа от обслуживания теневых финансовых потоков, генерируемых разными секторами экономики», что, на наш взгляд, является дискуссионным моментом.

С нашей точки зрения, подход к оценке экономической эффективности создания и реализации антимонопольного комплаенса должен быть идентичным оценке эффективности инвестиций любого инвестиционного проекта, в большей степени связанного с внедрением IT технологий, при этом не учитывая для простоты расчетов фактор времени и инфляцию, что в реальных условиях учитывать необходимо.

В принципе начинать необходимо с формирования единого перечня источников эффектив- ности создания и внедрения антимонопольного комплаенса с учетом идентичности каждого предприятия, равно как степени влияния показателей деятельности предпринимательской структуры и особенности рынков. Учитывая, что каждое предприятие представляет собой уникальное формирование, обладает своими компетенциями, ставит перед собой соответствующие стратегические задачи, и наконец, ключевые показатели эффективности производства, представляется невозможным формирование единого типового перечня источников экономического эффекта (результатов) Соответственно, для каждого предприятия влияние каждого из источников эффективности будет разным как по степени влияния на конечный результат, так и по форме возникновения.

После формирования определенного перечня источников эффективности, т.е. формирования соответствующих положительных эффектов, необходимо рассмотреть и реализовать возможность экономической оценки соответствующих эффектов, с тем, чтобы понимать, что предприниматель получит от внедрения антимонопольного комплаенса. Давно признано, что построение системы комплаенса является достаточно дорогостоящим мероприятием [4]. Это и затраты на обучение сотрудников, причем количество обучаемых может исчисляться тысячами (в качестве примера можно привести опыт МТС, где тренинги прошли уже 1000 сотрудников, включая топ-менеджмент [9]. Далее, это необходимость сертификации программ комплаенса специальной аккредитованной организацией, хотя существует мнение, что сертифицировать систему антимонопольного комплаенса или нет, является в полной мере прерогативой самого предприятия. Существует и ряд других затрат, связанных с техникой, программным обеспечением и др., которые необходимо оценивать при определении значимости антимонопольного комплаенса для конкретных предприятия. Однако необходима разработка методики оценки экономической эффективности антимонопольного комплаенса, позволяющей учесть как все затраты предприятий на внедрение данной системы, так и потенциальные выгоды, учитывающие возможность недополучения прибыли в случае нарушения антимонопольного законодательства. 


\section{Библиографический список}

1. Алешин M.M., Алешина Е.И. Комплаенс как инструмент повышения стоимости корпорации // Науковедение. Том 8, № 5 (2016). Интернет-журнал http://naukovedenie.ru/PDF/48EVN516.pdf.

2. Антимонопольный комплаенс: текущая практика и перспективы развития. Аналитический доклад Центра при Правительстве Российской федерации. декабрь 2015. ac.gov.ru.

3. Антимонопольный комплааенс в компаниях потребительского сектора. 3 февраля 2016 года. http://hvglaw. nl/Publication/vwLUAssets/ey-antitrust-compliance-mining/\$FILE/ey-antitrust-compliance-mining.pdf.

4. Ц Цыганов А. О внедрении антимонопольного комплаенса. 22 апреля 2016 года. https://fas.gov.ru/news/4164.

5. Мереминская Е. Освобождение от проверок ФАС как награда за введение комплаенса. https:/www.vedomosti. ru/economics/articles/2017/04/19/686315-osvobozhdenie-ot-proverok

6. Михненко Т.Н. Влияние антимонопольного комплаенса на эффективность функционирования хозяйствующих субъектов и экономики в целом // Мир науки. 2015. № 2. Интернет-журнал. http://mirnauki.com/ PDF/09KMN215.pdf.

7. Политика Группы компаний «Норильский Никель» в области антимонопольного комплаенса. https://www. nornickel.ru/files/ru/corporate_documents/policies/Antitrust-Compliance_Policy_201017-ru.pdf.

8. Тимошкин А.В. Экономическая эффективность комплаенс-контроля// Банковское дело. 2012. N7.

9. ФАС предлагает новую обязанность для госкомпаний - проверку антимонопольных рисков https://www. vedomosti.ru/economics/articles/2016/07/01/647547-fas-predlagaet-novuyu-obyazannost-dlya-goskompanii

10. Федеральный закон от 26.07.2006 N135-Ф3 (ред. от 29.07.2017) «О защите конкуренции».

Поступила в редакцию 30.12.2018 